\title{
ANALISIS KELEMBAGAAN IRIGASI BERBASIS KOMUNAL PADA DATARAN TINGGI (Studi Kasus Di Desa Tonasa Kecamatan Tombolopao Kabupaten Gowa)
}

\author{
Nurdin Mappa \\ Jurusan Agribisnis, Fakultas Pertanian, Universitas Muhammadiyah Makassar \\ E-mail: Nurdin.mappa@unismuh.ac.id
}

Diterima: 16 Maret 2020

Disetujui: 5 April 2020

\begin{abstract}
Irrigation institutions in Indonesia generally have two forms, first there are institutions built by the government, secondly institutions built by communities that are managed communally. This research aims to analyze the process of the formation of communal irrigation institutions, the structure and functions of irrigation institutions and analyze irrigation institutional rules communal, then compare it with other irrigation institutions. This research is a qualitative study with a case unit in Tonasa Village. Primary data obtained through interviews and secondary data obtained through data available from the relevant agencies. Data analysis was carried out by organizing data by sorting them into groups, involving the history of irrigation formation, institutional formation of the Water User Farmers Association (P3A), regulation of irrigation water use, irrigation maintenance, application of sanctions to communal members who violated existing rules agreed on a communal-based irrigation in Tonasa village, Buttonopao, Gowa district. The next step is the data will be synthesized to, search and find answers from the research questions and then publish it. The results showed that the irrigation institution of Tonasa Village was built from the bottom and already had a simple organizational structure and had regulations that were born from the community themselves, obeyed and enforced, for those who violated the sanctions imposed.
\end{abstract}

Keywords: Institutional, Irrigation, Communal, Plateau

\begin{abstract}
ABSTRAK
Kelembagaan irigasi di Indonesia secara umum ada dua bentuk, pertama ada kelembagaan yang dibangun oleh pemerintah, kedua kelembagaan yang dibangun oleh masyarakat yang dikelola secara komunal.Penelitian ini bertujuan untuk menganalisis proses terbentuknya kelembagaan irigasi komunal, struktur dan fungsi kelembagaan irigasi serta menganalisis aturan kelembagaan irigasi komunal, kemudian membandingkannya dengan kelembagaan irigasi yang lain. Penelitian ini merupakan penelitian kualitatif dengan unit kasus Desa Tonasa. Data primer diperoleh melalui wawancara dan data sekunder diperoleh melalui data-data yang tersedia dari instansi yang terkait. Analisis data dilakukan dengan mengorganisasikan data dengan memilah-milahnya dalam beberapa kelompok, menyangkut tentang sejarah terbentuknya irigasi, pembentukan kelembagaan Perhimpunan Petani Pengguna Air (P3A), pengaturan penggunaan air irigasi, pemeliharaan Irigasi, penerapan sanksi pada anggota komunal yang melakukan pelanggaran terhadap aturan yang sudah disepakati pada irigasi yang dikelola berbasis komunal di desa Tonasa kecamatan Tombolopao kabupaten Gowa. Langkah selanjutnya data akan disintesis untuk, mencari dan menemukan jawaban dari pertayaan penelitian kemudian mempublikasikannya. Hasil penelitian menunjukkan bahwa kelembagaan irigasi Desa Tonasa terbangun dari bawah dan sudah memiliki struktur organisasi yang sederhana serta sudah memiliki peraturan yang lahir dari masyarakat sendiri, dipatuhi dan ditegakkan, bagi yang melanggar ada sanksi yang diberlakukan.
\end{abstract}

Kata Kunci : Kelembagaan, Irigasi, Komunal, Dataran tinggi

\section{PENDAHULUAN}

Air bagi lahan pertanian merupakan kebutuhan yang sangat vital guna keberlanjutan pegelolaan lahan pertanian. Oleh karena itu air sangat penting untuk diatur agar dapat dimanfaatkan dengan baik oleh para petani guna mengairi lahan pertanian miliknya. Air yang tidak terkelola dengan baik, dapat menimbulkan kerawanan sosial di kalangan petani bahkan dapat menimbulkan kerusuhan di antara mereka, dan secara umum dapat menimbulkan kerawaan Keamanan ditengah-tengah masyarakat.

Kelembagaan pengelolaan air, ada yang terbentuk atas inisiatif dari pemerintah (top down) tertutama pada daerah-daerah yang memiliki instalasi irigasi teknis, yang dibangun oleh pemerintah. Organisasinya terbangun oleh 
pemerintah, termasuk kelembagaan perhimpunan petani pengguna air (P3A). Mereka mendapatkan kontrol dari pemerintah yang diperankan oleh seorang punggawa air. Semua sarana dan prasarana di dibiayai oleh pemerintah, bahkan petugasnya mendapatkan gaji atau honor dari pihak pemerintah.

Pada daerah-daerah tertentu masih terdapat pengelolaan irigasi yang tidak melibatkan pemerintah dalam pengelolaan irigasi. Petani selaku pengguna air melakukan pengelolaan irigasi secara swadaya yang berbasis komunal. Pengelolaan air dilakukan secara bersama-sama dalam bentuk gotong royong, mulai dari pembuatan irigasi, pemeliharaan, pembuatan aturan dan penerapan sanksi bagi petani yang tidak mematuhi aturan yang ada serta pembentukan kelembagaan Perhimpunan Petani Pengguna Air (P3A).

Salah satu komunitas yang melakukan pengelolaan irigasi secara Komunal adalah petani yang berada di desa Tonasa Kecamatan Tombolo Pao Kabupaten Gowa.Kelembagaan irigasi komunal yang berada di desa Tonasa Kecamatan Tombolopao dikelola oleh petani sudah berlangsung dalam waktu yang sangat lama dan kelola secara turun-temurun yang sampai sekarang masih eksis. Hal ini menarik untuk diteliti oleh karena banyaknya kelembagaan yang dibuat oleh pemerintah yang tidak dapat bertahan lama. Hal yang menarik untuk diteliti dari kelembagaa komunal ini adalah dari sisi proses kelahiran, struktur dan fungsi organisasinya dan rule of the game yang diberlakukan pada kelembagaan komunal ini.

Keberadaan irigasi bebasis komunal di

Desa Tonasa Kecamatan Tombolopao mengundang pertayaan di antaranya adalah:

1.Bagaimana proses penbentukan kelembagaan irigasi berbasis komunal di Desa Tonasa, kecamatan Tombolopao, dibandingkan dengan proses pembentukan kelembagaan irigasi lain?

2.Bagaimana Struktur dan Fungsi organisasi kelembagaan irigasi berbasis komunal di Desa Tonasa, Kecamatan Tombolopao, dibandingkan dengan kelembagaan irigasi lain?

3.Bagaimana aturan kelembagaan irigasi berbasis komunal di Desa Tonasa, Kecamatan Tombolopao, dibandingkan dengan aturan kelembagaan lain?

Adapun tujuan dari penelitian, disesuaikan dengan masalah penelitian yang dirumuskan yaitu:

1.Menganalisis proses penbentukan kelembagaan irigasi berbasis komunal di Desa
Tonasa, kecamatan Tombolopao, kemudian membandingkannya dengan proses pembentukan kelembagaan irigasi lain.

2.Menganalisis Struktur dan Fungsi organisasi kelembagaan irigasi berbasis komunal di Desa Tonasa, Kecamatan Tombolopao, kemudian membandingkannya dengan kelembagaan irigasi lain

3.Menganalisis aturan kelembagaan irigasi berbasis komunal di Desa Tonasa, Kecamatan Tombolopao, kemudian membandingkannya dengan aturan kelembagaan lain.

\section{METODE}

Penelitian ini menggunakan metode studi kasus, dengan unit kasus sebuah Desa di Kecamatan Tombolopao, Kabupaten Gowa, Provinsi Sulawesi Selatan, Indonesia. Fokus kasus adalah kelembagaan irigasi berbasis berbasis komunal. Daerah penelitian ini berada pada dataran tinggi dengan lahan agak miring, sekitar 25 sampai 30 derajat.

Pengambilan data dilakukan pada bulan juni sampai juli 2018. Adapun data yang dikumpulkan meliputi sejarah pembuatan irigasi, kondisi irgasi, struktur organisasi pengguna air irigasi, aturan yang diberlakukan. Pengumpulan data dilakukan melalui wawancara mendalam dengan petani pengguna air irigasi, Punggawa Mataere, tokoh masyarakat, pemerintah desa dan dusun. Data juga dikumpulkan melalui pengamatan langsung terhadap irigasi. Data yang diperoleh kemudian diklasifikasi berdasarkan keperluan dalam bentuk matriks, lalu diabstraksikan, selanjutnya memilih informasi kunci kemudian mengkoneksikan keterangan informan lain, kemudian mendeskripsikan selanjutnya menghubungkan dengan teori (Dey, 1993).

\section{HASIL DAN PEMBAHASAN}

\section{Hasil}

Proses Pembentukan Kelembagaan Irigasi di Desa Tonasa, Kecamatan Tombolopao

Irigasi di Desa Tonasa berinduk di saluran primer Sungai Tangara yang dikenal dengan nama Komponia. Irigasi ini dikenal dengan nama komponia oleh karena irigasi ini dibangun pada zaman Komponi Belanda sekitar tahun 1927. Pada tahun ini Belanda telah menjadikan Malino sebagai tempat peristirahatan.

Berdasarkan informasi dari tokoh masyarakat, pengadaan irigasi di Desa Tonasa 
pada awalnya diadakan secara swadaya oleh masyarakat Desa Tonasa secara bergotong royong. Kelembagaan irigasi ini tumbuh dan berkembang dari masyarakat sendiri, mulai dari sarana-prasarana sampai pada perumusan aturan kelembagaan.Kelembagaan perkumpulan petani pengguna air (P3A) terbentuk oleh masyarakat secara komunal tanpa campur tangan dari pemerintah. Pembentukan perkumpulann petani pengguna air di pelopori oleh tokoh masyarakat dengan cara musyarawah dihadiri oleh kepalakepala dusun. Kelembagaan irigasi pimpin oleh seorang punggawa yang dikenal dengan namaPunggawa Mataere.

Struktur dan Fungsi Organisasi Kelembagaan Irigasi di Desa Tonasa, Kecamatan Tombolopao

Kelembagaan Irigasi di Desa Tonasa tidak berada di bawah kewenangan pemerintah daerah maupun pusat, akan tetapi sepenuhnya di bawah kewenangan komunal yang kontrol oleh pemerintah setempat dalam hal ini kepala desa dan kepala dusun. Kelembagaan irigasi di Desa Tonasa sudah terbentuk dan setiap bagian dari struktur organisasi memiliki fungsi masingmasing. Pembentukannya diinisasi oleh tokohtokoh masyarakat dan dilakukan secara musyawarah oleh anggota komunal yang dihadiri oleh kepala desa dan kepala-kepala dusun.

Struktur organisasi kelembagaan irigasi Desa Tonasa terdiri atas Kepala Desa yang bertanggungjawab secara umum. Kepala Desa bertugas menyampaikan dan mengarahkan masyarakat untuk mengerjakan bangun fisik irigasi secara gotong royongjika memerlukan tenaga yang banyak, begitupula jika memerlukan dana untuk perbaikan irigasi. Di bawah Kepala Desa terdapat Punggawa Mataere yang bertugas mengatur dan membagi air.Kemudian di bawah Punggawa mataereadaketua kelompok pengguna air didampingi oleh bendahara dan sekretaris.Ketua bertugas mengkoordinir anggota pengguna air dalam melakukan setiap kegiatan yang berhubungan dengan irigasi sedangkan bendahara bertugas menagih dan menyimpan uang yang dipungut dari anggota kelompok pengguna air yang diperuntukkan pada perbaikan saluran irigasi tersier.Sedangkan sekretaris bertugas membuat undangan untuk pertemuan-pertemuan dan mencatat semua kegiatan yang dilakukan yang berhubungan dengan irigasi.Terakhir anggota pengguna air yang sewaktu-waktu digerakkkan bekerja secara gotong royong membersihkan dan memperbaiki saluran irigasi tersier, setiap menjelang musim panen yang dilakukan dua kali dalam setahun.

Kelembagaan irigasi di Desa Tonasa sudah menunjukkan keteraturan, yang diwujudkan dalam bentuk organisasi yang memiliki fungsi dan peran masing-masing yang sudah berjalan dengan baik.Sehingga kelembagaan komunal ini dapat diakui sebagai suatu kelembagaan yang sudah memenuhi definisi suatu kelembagaan yang sudah memenuhi kriteria seperti yang digambarkan oleh para ahli kelembagaan sekalipun masih bersifat komunal.Paling tidak seperti inilah yang disampaikan oleh Hayami dan Kikuchi (1987) bahwa kelembagaan adalah sekumpulan aturan mengenai tata hubungan manusia dengan lingkungannya yang menyangkut hak-hak, perlindungan hak-hak dan tanggungjawab serta suatu organisasi yang memiliki heirarki yaitu adanya mekanisme adimistrativ dan kewenangan.

Aturan Kelembagaan Irigasidi Desa Tonasa Kecamatan Tombolopao

Peraturan kelembagaan irigasi di Desa Tonasa belum dalam bentuk AD/ART, akan tetapi dalam bentuk kesepakatan-kesepakatan yang tidak tertulis, diantaranya adalah aturan dalam menjaga dan memelihara irigasi. Semua petani yang akan menggunakan air pada musim tanam diwajibkan untuk mengikuti kerja gotong royong, jika tidak sempat diwajibkan mengirimkan utusan sebagai pengganti. Kewajiban memelihara dan menjaga irigasi biasanya dilakukan tiga kali dalam satu musim tanam. Jika pengguna air tidak mengikuti kerja gotong royong, maka mereka tidak berhak menggunakan air irigasi selamasatu kali musim tanam.Lahan sawah diserahkan kepada Punggawa Mataere untuk mengelola sawahnya sampai musim tanam berikutnya.Pengaturan air dilakukan pada saat musim kekurangan air dengan cara menjadwal penggunaan air.Jadwalpemberian air dibagi dua yaitu siang dan malam.Bagi yang mengambil air disiang hari, mereka tidak boleh mengambil air dimalam hari.Pelanggaran pada jadwal mengakibatkan mereka tidak mendapatkan hak pengambilan air pada musim tanam itu.Cara pembagian air dimulai dari hilir berturut-turut sampai hulu.

\section{Pembahasan}

Irigasi di Desa Tonasa Kecamatan Tombolopao sudah berbentuk kelembagaan sekalipun bersifat komunal, oleh karena pengelolaan irigasi sudah dilengkapi dengan organisasi yang di dalamnya sudah ada 
penerapan aturan yang sudah disepakati dan ditegakkansecara bersama-sama, serta memiliki tujuan bersama.Hal ini diakui oleh North (1991) bahwa kelembagaan mengandung makna aturan main yang dianut oleh masyarakat atau anggota yang dipedomani oleh seluruh anggota masyarakat atau anggota organisasi dalam melakukan transaksi.

Kelembagaan irigasi di Desa Tonasa sangat cocok dengan kondisi masyarakat dan cendrung lebih bisa bertahan, hal ini dapat dibuktikan pada kelembagaan irigasi di Desa Tonasa Kecamatan Tombolopao Kabupaten Gowa, yang sudah berlangsung lama secara turun-temurun yaitu mulai dari zaman kompeni sampai sekarang. Kelembagaan ini tumbuh dan berkembang dari masyarakat. Sesuatu yang tumbuh dari kesadaran masyarakat cendrung mereka menjaganya, apalagi kalau mereka menganggapnya sebagai nilai leluhur dari nenek-nenek mereka, dan nilai ini ada pada masyarakat Desa Tonasa, oleh karena kelembagaan irigasi ini sudah berlangsung secara turun-temurun. Sementara pembentukan kelembagaan yang dirancang dari top down biasanya tidak sesuai dengan kondisi masyarakat yang sudah memiliki krasteristik tersendiri (Pasandaran dan Taryoto, 1993). Kebijakan dari atas sering berbenturan dengan nilai-nilai yang sudah berlaku ditengah-tengah masyarakat sehingga masyarakat tidak dapat mengadopsi kelembagaan dan aturan yangterkesan dipaksakan kepada mereka, maka jangan heran kemudian kelembagaan irigasiyang dirancang oleh pihak pemerintah menjadi tidak berkelanjutan. Dibandingkan dengan kelembagaan irigasi yang terbangun dari masyarakat sendiri, seperti yang terjadi di Desa Tonasa Kabupaten Gowa. Kondisi ini diakui oleh Pasandaran dan Taryoto (1993) yang mengungkapkan bahwa berbagai pengaturan irigasi yang berorientasi pada upaya generalisasi kebijakan, tanpa memperhatikan norma-norma setempat seringkali menghadapi hambatan. Karena itu, dalam sistem kemasyarakatan yang majemuk seperti yang ada di Indonesia, pertimbangan kekhasan masing-masing masyarakat atau wilayah seyogyanya harus mendapat pertimbangan. Bahkan dalam menggagas rancangan unit pengelola irigasi modern di Indonesia Angguniko dan Hidayah (2017) merekomendasikan agar sebuah struktur kelembagaan didasarkan pada tipologi masingmasing daerah irigasi.
Kelahiran kelembagaan irigasi di Desa Tombolopao mirip dengan kelahiran Kelembagaan Irigasi Subak di Bali yang dilatar belakangi oleh Tri Hita Karana (THK) yaitu merupakan sebuah landasan yang bersumber dari agama Hindu. Namun sejatinya konsep ini adalah konsep universal yang eksis dalam kehidupan setiap umat beragama di dunia. Disebut eksis karena THK pada intinya mengedepankan harmoni dan prinsip-prinsip kebersamaan dalam kehidupan umat manusia (Windia, 2006). Pada kelembagaan irigasi di Desa Tonasa prinsip harmoni dan kebersamaan diwujudkan dalam bentuk kerja gotong royong, terutama dalam menjaga, memelihara dan memperbaiki irigasi. Partisipasi aktif dari anggota kelembagaan irigasi Desa Tonasa telah mendorong lahirnya kelembagaan irigasi komunal, sekaligus mengakibatkan terpeliharanya saluran irigasi, hal ini di akui oleh Anonim (2017) bahwa Dalam upaya pelibatan dan peningkatan peran masyarakat dalam pengelolaan sumber daya air maka strategi yang dapat digunakan adalah pemberdayaan masyarakat. Dengan adanya upaya pemberdayaan diharapkan masyarakat dapat meningkatkan pengetahuan, pemahaman serta kemampuannya untuk melakukan aktivitas yang tercakup dalam pengelolaan sumber daya air, baik dalam hal konservasi, pendayagunaan maupun pengendalian daya rusak air.

Setiap akan masuk musim tanam kebersamaan dan kerjasama dari anggota perkumpulan petani pengguna air (P3A) selalu bekerjasama dengan cara bersama-sama turun memperbaiki saluran yang mengalami kerusakan secara pisik, dipimpin oleh Punggawa Mataere. Kerjasama yang dilakukan dalam bentuk gotong royong, ini menunjukkan bahwa pengelolaan irigasi yang dilakukan secara turuntemurun sudah betul-betul menjadi budaya masyarakat di Desa Tonasa. Kegiatan kerjasama ini terjaga oleh karena irigasi merupakan urat nadi bagi kehidupan mereka dalam melakukan usahatani. Tanpa ada irigasi usahatani tidak dapat dilakukan akibatnya kehidupan mereka terancam, oleh karena sumber kehidupan utama sebagai seorang masyarakat desa tidak dapat dijalankan. Itulah sebabnya kegiatan kerjasama dalam pengelolaan irigasi sangat terjaga dengan baik.

Salah satu unsur dari suatu kelembagaan yang harus terpenuhi sehingga suatu pranata sosial dianggap sebagai suatu kelembagaan oleh karena adanya aturan yang dibuat dan disepakati 
serta ditegakkan, hal ini disampaikan oleh Eaton (1986). Pertaturan kelembagaan irigasi di Desa Tonasa dirumuskan dan disepakati oleh masyarakat tani sendiri dan sudah berlangsung secara turun-temurun, sejak nenek moyang mereka membuka lahan. Peraturan yang telah disepakati telah membuat kelembagaan irigasi di Desa Tonasa dapat berjalan dengan baik. Para petani mematuhi aturan yang telah dibuat. Mereka menyadari bahwa aturan yang telah berjalan dengan baik membuat kelembagaan irigasi dapat berfungsi dan memberi manfaat kepada mereka. Tidak ada anggota komunal yang dapat bertindak semena-mena menggunakan air irigasi hanya karena mereka memiliki kuasa di tengah-tengah komunalnya.

Mereka memiliki kesamaan hak dan kewajiban sebagai anggota komunal dalam kelembagaan irigasi terutama dalam mengakses air untuk lahan mereka. Pelanggaran terhadap jadwal yang telah disepakati yang berujung pada sanksi, yakni tidak boleh mengambil lagi air selama musim tanam, sehingga konflik di antara para petani pengguna air jarang terjadi, Penjadwalan ini dilakukan pada masa debit air berkurang, terutama musim kemarau, sementara pada musim hujan tidak ada pembatasan penggunaan air, hal ini mirip dengan yang disampaikan oleh Najamuddin, dkk (2014) bahwa pendekatan yang digunakan sebagai dasar pengaturan distribusi air adalah pendekatan dari segi keseimbangan antara ketersediaan air dengan kebutuhan air untuk tanaman.

Kebersamaan lain diantarannya ditunjukkan dalam hal pembiayaan, yang dilakukan secara bersama-sama dengan cara mengumpulkan sumbangan anggota pengguna air. Jika perbaikan membutuhkan sejumlah anggaran, maka anggaran yang dibutuhkan ditanggung bersama oleh anggota komunal. Pembayaran dilakukan dengan menggunakan uang secara tunai. Pembayaran dilakukan tidak rata tapi disesuaikan dengan luas lahan yang digarap oleh pengguna air irigasi, hal ini berbeda dengan yang disampaikan oleh Fardiyanti (2017) dimana iuran sudah ditetapkan perhektar/tahun. Pada kelembagaan irigasi Desa Tonasa pembayaran iuran tidak ditetapkan, pemilik lahan yang agak luas membayar lebih banyak dibandingkan dengan pemilik lahan yang lebih sempit. Pembayaran dilakukan sebelum pekerjaan perbaikan irigasi di lakukan dan biasanya dilakukan sebelum musim tanam, oleh karena perbaikan dilakukan sebelum musim tanam di mulai, sehingga dalam setahun dilakukan dua kali pembayaran yaitu sekitar bulan Juni dan Januari. Partisipasi anggota komunal kelembagaan irigasi dalam pembayaran untuk pengelolaan irigasi telah membuat irigasi ini terawat dan masih dapat difungsikan dengan baik, hal ini sesuai dengan temuan Jannata, dkk (2015) yang telah meneliti Irigasi Lemor, bahwa pengelolaan jaringan irigasi Daerah Irigasi Lemor efektif karena masih tingginya partisipasi petani dalam proses pembiayaan maupun dalam hal pemeliharaan saluran. Pada sisi keuangan kelembagaan irigasi Desa Tonasa, sudah ada kemandirian oleh karena pembiyaan semuanya berasal dari anggota komunal, hal ini telah disarankan oleh Murtiningrum, dkk (2015), bahwa untuk mengatasi kelemahan aspek keuangan Gabungan Perkumpulan Petani Pemakai Air (GP3A), diperlukan upaya penggalian sumber dana mandiri.

Kebersamaan lain adalah kerja gotong royong yang dilakukan secara bersama-sama ketika melakukan pembersihan dan perbaikan irigasi, yang biasanya dilakukan dua kali dalam setahun. Sedangkan kesamaan hak adalah mereka memiliki hak yang sama dalam menggunakan air irigasi, tanpa ada perbedaan, mereka dapat mengakses air irigasi sesuai dengan aturan yang telah ditetapkan dalam komunal. Kerjasama yang dilakukan oleh anggota komunal telah membuat kondisi fisik irigasi di Desa Tonasa dapat terjaga dengan baik sehingga dapat difungsikan oleh anggota komunal selama bertahun-tahun, hal ini berbeda dengan temuan Indriastuti dan Muktiali (2015), yang menemukan adanya commons dilemma yang terjadi pada pengelolaan daerah Irigasi Kapiler merupakan suatu kondisi dimana pengelolaan sumber daya air dihadapkan pada lemahnya kerjasama antar pengguna sehingga berdampak buruk pada kondisi fisik sumber daya itu sendiri hingga akhirnya timbul persaingan antar pengguna di irigasi Kabupaten Klaten.

Struktur organisasi kelembagaan irigasi di Desa Tonasa Kabupaten Gowa terhenti pada kepala desa sebagai penanggungjawab dan secara struktural tidak ada hubungan dengan pemerintah di atasnya, bahkan belum pernah mendapatkan bantuan dari pemerintah dalam rangka perbaikan atau pemeliharaan irigasi, padahal kewenangan irigasi sudah diatur oleh pemerintah sehingga seharusnya irigasi di Desa Tonasa berada pada pemerintah daerah oleh 
karena irigasi ini mengairi lahan di bawah 1.000 ha akan tetapi pemerintah tidak ikut campur tangan oleh karena irigasi ini termasuk jaringan irigasi sederhana, keadaan ini sesuai dengan apa yang dijelaskan oleh Absor (2008) bahwa dalam jaringan irigasi sederhana para petani pemakai air itu tergabung dalam satu kelompok jaringan irigasi yang sama, sehingga tidak memerlukan keterlibatan pemerintah di dalam organisasi jaringan irigasi semacam ini. hal ini berbeda dengan kelembagaan irigasi lain yang dibangun langsung oleh pemerintah yang berupa proyek biasanya berada di bawah kewenangan pemerintah pusat jika luas lahan yang dialiri lebih dari 3.000 ha, jika luasnya yang dialiri 1.000 sampai 3.000 kewenangan berada di pemerintah provinsi dan kurang dari 1.000 ha daerah yang dialiri kewenangan berada pada pemerintah daerah kabupaten (Anonim, 2015).

\section{KESIMPULAN}

Berdasarkan hasil dan pembahasan pada penelitian ini maka dapat diambil kesimpulan sebagai berikut :

1. Kelahiran kelembagaan irigasi di Desa Tonasa Kabupaten Gowa berasal dari kesadaran masyarakat, bukan atas intervensi dari pihak luar baik oleh kelembagaan pemerintah maupun swasta, sementara kelembagaan yang dibangun oleh pemerintah biasanya diinisiasi oleh pihak pemerintah.

2. Kelembagaan irigasi di Desa Tonasa memiliki struktur yang terdiri atas Kepala Desa yang merupakan penanggungjawab secara umum, Punggawa Mataere sebagai pengatur air, dan ketua yang didampingi oleh sekretaris dan bendahara sebagai pengelola kegiatan irigasi serta anggota yang merupakan pengguna air irigasi. Sementara struktur kelembagaan yang dibangun oleh pemerintah melibatkan pemerintah di atas kepala desa.

3. Peraturan pada kelembagaan irigasi di Desa Tonasa dibangun oleh anggota komunal sendiri tanpa AD/ART, sementara peraturan pada kelembagaan yang dibangun oleh pemerintah telah ada dari atas dan biasanya diformalkan dalam bentuk AD/ART.

\section{UCAPAN TERIMA KASIH}

Ucapan terima kasih kepada Bapak Rektor Unismuh Makassar yang telah memberikan izin dan kesempatan untuk melakukan penelitian dan telah menbantu fasilitas, begitupula ucapan terima kasih kepada kepala Desa Tonasa Kecamatan Tombolopao Kabupaten Gowa Sulawesi Selatan yang telah memberi izin untuk melakukan penelitian di Wilayah begitupula kepada masyarakatnya yang telah memberikan informasi atau data-data yang diperlukan dalam penelitian ini. Ucapan terima kasih pula saya sampaikan kepada Meristekdikti yang telah membiayai penelitian ini. Mudah-mudahan apa yang telah kita lakukan dapat bermanfaat dan menjadi amal jariah untuk kita semua, Amiin.

\section{DAFTAR PUSTAKA}

Badan Pusat Statistik. 2017. Kabupaten Nunukan dalam angka 2017. BPS Kabupaten nunukan. Kabupaten Nunukan.

Harsono,Boedi, 2008, Hukum Agraria Indonesia: Sejarah Pembentukan Undang-Undang Pokok Agraria, Isi Dan Pelaksanaannya, Djambatan, Jakarta.

Harsono, 2010, Hukum Agraria Indonesia: Sejarah Pembentukan Undang-Undang Pokok Agraria, Isi Dan Pelaksanaannya, Djambatan, Jakarta.

Peraturan Kepala BPN/Menteri Negara Agraria Nomor 3 Tahun 1997 Tentang Pelaksanaan PP Nomor 24 / 1997.

Peraturan Menteri Dalam Negeri Nomor 6 Tahun 1972 Tentang Pelimpahan Wewenang Pemberian Hak Atas Tanah.

Peraturan Menteri Pertanian Republik Indonesia Nomor 98/Permentan/ot.140/9/2013 Tentang Pedoman Perizinan Usaha Perkebunan.

Peraturan Pemerintah No. 10 Tahun 1961 tentang Pendaftaran Tanah, Jakarta.

Peraturan Pemerintah Nomor 24 Tahun 1997 tentang Pendaftaran Tanah.

Peraturan Pemerintah Nomor 24 Tahun 1997 Tentang Pendaftaran Tanah

Peraturan Pemerintah Nomor 38 Tahun 1963 Tentang Penunjukan Badan-Badan Hukum Yang dapat Mempunyai Hak Milik atas Tanah.

Peraturan Pemerintah Nomor 40 Tahun 1996 Tentang Hak Guna Usaha, Hak Guna Bangunan dan Hak Pakai.

Sutrisno Adi. 2012. Analisis Persepsi dan Motivasi Petani Terhadap Manfaat Sumberdaya Hutan Lindung Pulau Tarakan. Institut Pertanian Bogor

Peraturan Kepala BPN/Menteri Negara Agraria Nomor 3 Tahun 1997 Tentang Pelaksanaan PP Nomor 24 / 1997.

Peraturan Menteri Pertanian Republik Indonesia Nomor 98/Permentan/ot.140/9/2013 Tentang Pedoman Perizinan Usaha Perkebunan.

Peraturan Pemerintah Nomor 24 Tahun 1997 tentang Pendaftaran Tanah. 
Undang-Undang Nomor 5 Tahun 1960 Tentang Peraturan Pokok-Pokok Agraria.

Undang-Undang No. 56/Prp/1960, Penetapan Luas Tanah Pertanian.

Undang-Undang Nomor 39 Tahun 2014 Tentang Perkebunan.Absor M. 2008, Modul Bahan Ajar Irigasi I - II, Politeknik Negeri Sriwijaya. Jurusan Teknik Sipil. Palembang.

Angguniko, B.Y dan Hidayah, S. 2017. Rancangan Unit Pengelola Irigasi Modern di Indonesia. http://jurnalirigasi_pusair.pu.go.id/index.php/ju rnal_irigasi/article/view/173, Vol 12, No.1, hal 23-36. Diakses tanggal 27/10/2018

Anonim, 2015.Peraturan Menteri Pekerjaan Umum Dan Perumahan Rakyat Republik Indonesia Nomor 14 /Prt/M/2015 Tentang Kriteria Dan Penetapan Status Daerah Irigasi, Menteri Pekerjaan Umum Dan Perumahan Rakyat Republik Indonesia.

Anonim, 2017. Buku Sumber Daya Air, Provinsi Jawa Barat, Balai Pusat Data Dan Informasi Sumber Daya Air, Bandung.

Dey, I., 1993. Qualitative data analysis A userfriendly guide for social Scientists, Routledge Taylor and Francis Goroup. London and New York.

Eaton, J.W. 1986. Pembangunan Lembaga dan Pembangunan National: Dari Konsep Kegiatan Aplikasi. Terjemahan. Cetakan Pertama. Universitas Indonesia Press.Jakarta

Fardiyanti, D. 2017 Analisis Sistem Pengelolaan Air Irigasi, Keragaan Usahatani Padi dan Pembayaran Iuran Irigasi (Studi Perbandingan Antara Sistem Pembagian Air Kontiniu pada Irigasi Teknis dengan Pembagian Air Giliran pada Irigasi Pompa) http://repository.ipb.ac.id/handle/123456789/21 497, di akses tanggal 27/10/2018.

Hayami, Y. dan Kikuchi, M. 1987 Dilema ekonomi Desa: Suatu Pendekatan Ekonomi terhadap Perubahan Kelembagaan di Asia. Yayasan Obor Indonesia.Jakarta

Indriastuti,W. dan Muktiali, M.2015. Commons Dilemma pada Pengelolaan Daerah Irigasi Kapilaler, Kabupaten Klaten, Jurnal Wilayah Dan Lingkungan Vol. 3 No 2, Hal. 105-120.

Jannata, Abdullah, S.H., dan Priyati A., 2015. Analisa Kinerja Pengelolaan Irigasi Di Daerah Irigasi Lemor,Kabupaten Lombok Timur, Nusa Tenggara Barat, Jurnal Ilmiah Rekayasa Pertanian dan Biosistem, Vol.3, No. 1, hal 112121.

Mutiningrum, dkk. 2016. Implementatiom of Decisin Support System foor Monitoring and Evaluation od Performance in Distric CrossBoundry Irigation System. Prosiding disampaikan dalam Seminar International Symposium of Agricultural and Biosystem Enginering (ISABE) 9 -11 Agustus 2016.
Universitas Mataram Lombok (tidak dipublikasikan).

Nadjamuddin, F.D., Soetopo, W., Sholichin,M. 2014. Rencana Penjadwalan Pembagian Air IrigasiDaerah Irigasi Paguyaman Kanan Kabupaten Boalemo provinsi Gorontalo Jurnal Teknik Pengairan, Vol. 5, No.2, hlm 158-165

Noth, Douglas, C. 1991. Institution". Journal of Economy Perspectives, 5:97-112.

Pasandaran, E. dan A. Taryoto. 1993. Petani dan Irigasi : Dua Sisi Mata Uang. Lokakarya Pembangunan Berkelanjutan dan Penanggulangan Kemiskinan di Tingkat Lokal, Bogor 15-17 Juni 1993, PSE, Bogor.

Windia,W. 2006. Transformaasi Sistem Irigasi Subak yang BerlandaskanTri Hita Karana. Denpasar: Penerbit Bali Post. 